\title{
FOREWORD
}

\section{The Anthropology of Ontology Meets the Writing Culture Debate-Is Reconciliation Possible?}

Rane Willerslev

This exciting special issue sets out to take the 'anthropology of ontology' (also called the 'ontological turn'), along with its concern for indigenous animism, to a new level of analysis by pairing it with key issues originally raised by anthropology's influential paradigm of reflexivity, the Writing Culture debate. A few years ago, I critiqued the inclination "to neutralize the challenge" that animistic ideas present to anthropological thinking (Willerslev 2007: 12). In their introduction, the editors of this issue, Katherine Swancutt and Mireille Mazard, describe the 'reflexive feedback loop' through which native thinkers, by adopting anthropological theories of animism, cast the anthropological gaze back upon itself. Here, instead of being neutralized by anthropology, native ideas feed into and play havoc with scholarly models of animism. It is this unexpected condition of inquiry that gives rise to the editors' engagement with the 'anthropology of anthropology'.

In certain ways, this echoes the 1980s postmodern critique of anthropology and the paradigm of reflexivity that became its answer (see Clifford 1986: 17). However, the articles in this special issue take the theories of the Writing Culture debate in a new and important direction by offering novel insights into wider social movements-communism, Christianity, environmentalism, Daoist revivals, socialism, post-socialism, spiritualism-that shape local thinkers', and subsequently professional anthropologists', ideas about animism. The contributors further highlight changes to animism resulting from knowledgemaking practices such as techno-science, popular fiction, and autobiographical narratives, all of which can be said to lie beyond the state-of-the-art concerns of the anthropology of ontology.

The editors' argument about reflexive native thinkers also evokes the much older notion of the 'savage philosopher', a term introduced by the 'father of animism', Edward B. Tylor ([1871] 1920). I shall return to address Tylor's legacy and the reflexive native thinker in a moment. For now, I want to consider the 
implications of the daring route tackled by Swancutt and Mazard, which seeks to bring together the Writing Culture paradigm, the primary theory of reflexivity of the 1980s, with the theory currently in fashion in the study of animismthe anthropology of ontology.

\section{The Reflexivity of Writing Culture versus Alterity in the Anthropology of Ontology}

I consider the route 'daring' because the paradigms that the editors seek to unite are, at least on the face of it, deeply at odds. The Writing Culture paradigm does not believe in radical alterity. Rather, it suggests that we all live in a globalized world in which the high speed of communication and the wide range of intercultural connections make all the talk about absolute alterity meaningless. As George Marcus (2007: 7), one of the founding fathers of the paradigm, puts it: "[Today] few anthropologists would set out on research in the contemporary world while laying claim to this pure purpose for ethnographic inquiry of exploring cultural alterity as 'Other'." It comes as no surprise, therefore, that many of this paradigm's devotees are passionately engaged in the study of globalization (Smith and Guarnizo 1998) and the use of new digital technologies of communication (Pfaffenberger 1992), often by means of 'multi-sited' ethnographic fieldwork in urban settings (Falzon 2009).

The anthropology of ontology, by contrast, marks a return to 'ethnographic orthodoxy' through its concern for uncovering the radical alterity of others (Willerslev 2013c: 42). This radical alterity is supposed to be found primarily in small-scale communities in Amazonia (Viveiros de Castro 1992), Melanesia (Scott 2007), Mongolia (Pedersen 2011), and Siberia (Willerslev 2009, 2013c). It is within these apparently marginal communities that anthropologists hope to find alien concepts of the soul, spirits, and non-human persons that fly in the face of Western common-sense understandings of what reality entails (Candea 2011). Anthropology's greatest task, according to ontologists, is to embrace this alterity and incorporate it into its scripts, so as to alter our own ways of thinking about what constitutes the real (Holbraad 2007; Scott 2013; Viveiros de Castro 2011; Willerslev 2013b).

This fundamental difference between the two paradigms is perhaps revealed above all in their disparate take on the recurrent problem of 'cultural translation'. The Writing Culture paradigm sees the problem as one of 'representation'-that is, people impose different schemes of meanings upon the same reality, which is considered exterior to cultural representation (Burr 2003: 6). In this sense, it is presumed that there is a basic level of univocality-one that underlies what others and we are saying. The anthropology of ontology, in contrast, presupposes that an enormous gap divides indigenous ontologies from that of Euro-America. Hence, there is no common baseline that would work as a mutual referent for transcultural dialogue, since "we and they are never talking about the same things" (Viveiros de Castro 2004: 7). Cultural translation becomes in this view a matter of "controlled equivocation" (ibid.), a method of comparison that aims 
at keeping ontological differences in view (Willerslev 2013a: 142). Now, this is not the place to discuss which of the two paradigms is more persuasive. What is more important to Swancutt and Mazard is the prospect of bringing the paradigms together in an anthropological effort to come to grips with the shifting nature of animism. The task is difficult, and whether this collection is successful in its aim is up to the reader to judge. When perusing the articles, I experienced a number of revelations that I will briefly share here.

\section{Metaphysical Animism and the Native Point of View}

First, by coupling the anthropology of ontology's passion for alien concepts with the Writing Culture paradigm's passion for reflexivity and global interconnectivity, animism comes to be seen as an intellectual endeavor, a product of high-level abstract thinking. In some ways, this echoes Tylor's notion of the 'savage philosopher', who attempts to provide intellectual explanations for the causal workings of the world by invoking images of spirits, souls, and the like. This take on animism as being parallel to philosophy is radically different from how it has mostly been depicted during the past two decades. The dominant view has linked animism with 'efficacy' - that is, animist beliefs have been understood to be in some fundamental sense practical, inseparably bound up with the hands-on concerns of everyday life (see, e.g., Humphrey and Onon 1996; Ingold 2000; Willerslev 2007). In this viewpoint, animism is not necessarily considered to be metaphysically significant with some 'higher role' that would imply providing its practitioner with a deeper insight into the mysteries of life (Willerslev 2004; 2013a: 144). Instead, animism has been understood to be primarily concerned with profane questions of cost and gain. Caroline Humphrey and James Laidlaw (1994: 11) encapsulate this notion in relation to animism's twin concept of shamanism, stating that "the question most insistently asked of [shamans is] 'Has it worked?'” Here, animism is the reverse side-indeed, the antithesis of-philosophy. This special issue's introduction of the 'hyper-reflexive' animist thinker is a decisive break with this view.

A few years ago I argued for a return to a Frazerian style of anthropology in the sense that metaphysical speculation, rather than the usual Malinowskian trust in empirical studies, is needed if we are to unlock the animist concept of 'soul' (Willerslev 2011). In this view, the anthropologist's speculative imagination becomes a counterpoint to empirical ethnographic research. Swancutt and Mazard make an argument that is somewhat parallel to this: they show that native metaphysics is a counterpoint to the native practice of animism. The two are not incompatible, and the existence of animism as the fabric of everyday practical life does not exclude the possibility of an 'armchair anthropology' of animism among its practitioners.

This is, in my view, one of the key insights revealed in this special issue. Indigenous animism is, due to the 'reflexive feedback loop', undergoing a major change in which its concern with efficacy is increasingly being replaced with metaphysical concerns. This transformation has deep-seated implications for 
how anthropologists can go about studying animism, since it implies novel forms of dialogue, partnership, and perhaps even co-authorship-that is, all the reflexive concerns of the 'anthropology of anthropology'.

This leads me to the next revelation, which has to do with the need to revise the status of anthropological knowledge vis-à-vis the so-called native point of view. The editors and contributors to this special issue are talking about parallel knowledge-making practices-those of native thinkers and those of anthropologists that feed into each other. Whether or not they regard the two types of knowledge practices as being somehow equal or even equivalent is uncertain. However, I believe it is worth pursuing a clearer answer by asking what the articles reveal about the matter. In the face of the postmodernist crisis, Kirsten Hastrup (1993) makes the thorny argument that anthropological knowledge is fundamentally different from, and by no standards reducible to, the native point of view. She states that the "native point of view is part of ethnography, but the goal of scholarship is not just to record the world as seen from a particular point of view ... As science, anthropology aims at general truth, which lies beyond any particular narrative" (ibid.: 176). She adds that "there is no way in which one can claim privileged access to anthropological knowledge-except by being native to anthropology" (ibid.: 181; original emphasis).

Hastrup has a point all right, but as this issue quite clearly illustrates, the categories of both 'native' and 'anthropologist' are not unambiguous, straightforward, or uniform. Modern-day anthropology is not immune from being bamboozled by the sophistication of native animist thinking, just as native thinkers are not 'theory free', devoid of metaphysical thought. If we miss out on the complexity of the relationship between native thinkers and the various theories, cosmologies, or ideologies that shape their ways of understanding animism, then we are missing out on the complexity of the present day's native point of view. This is true even in the most remote corners of the world. What are the implications of this for the status of anthropological knowledge versus the native point of view? The implications, I venture to argue, are substantial. Several of the articles in this issue confront us with cases of interactions that blur the finite and fixed idea of the professional anthropologist as being someone manifestly different from the native.

Swancutt's article on the Nuosu discusses a native anthropologist named Tuosat, who cannot by any academic standards (even by the strict criteria endorsed by Hastrup) be denied the legitimacy of being a professional anthropologist. The same goes for Olga Ulturgasheva. An Eveny from a small remote Siberian village who was trained in anthropology at Cambridge, her research monograph details ethnographic fieldwork that she conducted in her native community (see Ulturgasheva 2012). Likewise for Kathleen Richardson, who, as an anthropologist, writes about her own native Euro-American society. On another level, Diana Espírito Santo analyzes how her interlocutors, including those spirits in the Cuban or Brazilian cosmos who set in motion their own processes of self-becoming, influence her place in fieldwork dialogues and recursive processes of anthropological theory making. Furthermore, we meet in this issue native thinkers, such as Ayima and Ahuo in Mazard's article, 
who are not and do not pretend to be anthropologists, yet they debate with high sophistication about the metaphysical commonalities and divergences between animistic and Christian cosmologies.

All of this means that the native point of view is rife with intellectual vigorso much so that it seems meaningless to reduce it to a particular culturally situated point of view, as opposed to the anthropologist's generalized scientific view (cf. Hastrup 1993: 176). Whether or not all of these new hyper-reflexive native voices are equivalent to anthropological knowledge (although some clearly are) also seems to be a moot point. What is critical is that we need to take their metaphysics seriously and allow them not only to influence but also to rejuvenate our theories of animism.

Finally, in many of the articles I read a meta-message that I find highly pertinent. While the majority of the authors are firmly committed to the anthropology of ontology, they all signify that this paradigm, if it is to provide a viable route for the future of anthropology, needs to take seriously (just as it takes indigenous animism seriously) the insights about globalization and reflexivity that grew out of the Writing Culture debate. If not, there is a real risk that the 'radical orthodoxy' of the anthropology of ontology will end up on the historical junkyard of failed anthropological doctrines. What makes this special issue unique is that it is the first serious attempt at merging the two arguably most influential theoretical paradigms of contemporary anthropology, and this, I want to stress, has important implications for how anthropology will develop in the future.

Rane Willerslev is a Professor of Anthropology at Aarhus University. He is the author of Soul Hunters (2007) and On the Run in Siberia (2012). His main field of research has been among Siberia's indigenous peoples (Yukaghirs and Chukchi), and he has recently started conducting fieldwork among the Ik of northern Uganda. While the overall bulk of his work has been within the anthropology of religion, addressing themes such as the 'new animism', his publications cover a wide spectrum of classical and more current anthropological interests, including experimental methodology, human security, and the interface between anthropology, biology, and archaeology.

\section{References}

Burr, Vivien. 2003. Social Constructionism. 2nd ed. New York: Routledge.

Candea, Matei. 2011. "Endo/Exo.” Common Knowledge 17, no. 1: 146-150.

Clifford, James. 1986. "Introduction: Partial Truths.” Pp. 1-26 in Writing Culture: The Poetics and Politics of Ethnography, ed. James Clifford and George E. Marcus. Berkeley: University of California Press.

Falzon, Mark-Anthony, ed. 2009. Multi-sited Ethnography: Theory, Praxis and Locality in Contemporary Research. Burlington: Ashgate.

Hastrup, Kirsten. 1993. "The Native Voice—and the Anthropological Vision." Social Anthropology 1, no. 2: 173-186. 
Holbraad, Martin. 2007. "The Power of Powder: Multiplicity and Motion in the Divinatory Cosmology of Cuban Ifá (or Mana, Again).” Pp. 189-225 in Thinking Through Things: Theorising Artefacts Ethnographically, ed. Amiria Henare, Martin Holbraad, and Sari Wastell. London: Routledge.

Humphrey, Caroline, and James Laidlaw. 1994. The Archetypal Actions of Ritual: A Theory of Ritual Illustrated by the Jain Rite of Worship. Oxford: Clarendon Press.

Humphrey, Caroline, with Urgunge Onon. 1996. Shamans and Elders: Experience, Knowledge, and Power among the Daur Mongols. Oxford: Clarendon Press.

Ingold, Tim. 2000. The Perception of the Environment: Essays on Livelihood, Dwelling and Skill. London: Routledge.

Marcus, George E. 2007. “Collaborative Imaginaries.” Taiwan Journal of Anthropology 5, no. 1: 1-17.

Pedersen, Morten Axel. 2011. Not Quite Shamans: Spirit Worlds and Political Lives in Northern Mongolia. Ithaca, NY: Cornell University Press.

Pfaffenberger, Bryan. 1992. "Social Anthropology of Technology." Annual Review of Anthropology 21: 491-516.

Scott, Michael W. 2007. The Severed Snake: Matrilineages, Making Place, and a Melanesian Christianity in Southeast Solomon Islands. Durham, NC: Carolina Academic Press.

Scott, Michael W. 2013. "What I'm Reading: The Anthropology of Ontology (Religious Science?)" Journal of the Royal Anthropological Institute 19, no. 4: 859-872.

Smith, Michael P., and Luis E. Guarnizo, eds. 1998. Transnationalism from Below. New Brunswick, NJ: Transaction Publishers.

Tylor, Edward B. [1871] 1920. Primitive Culture: Researches into the Development of Mythology, Philosophy, Religion, Language, Art, and Custom. Vols. 1 and 2. London: John Murray.

Ulturgasheva, Olga. 2012. Narrating the Future in Siberia: Childhood, Adolescence and Autobiography among Young Eveny. New York: Berghahn Books.

Viveiros de Castro, Eduardo. 1992. From the Enemy's Point of View: Humanity and Divinity in an Amazonian Society. Trans. Catherine V. Howard. Chicago: University of Chicago Press.

Viveiros de Castro, Eduardo. 2004. "Perspectival Anthropology and the Method of Controlled Equivocation." Tipití 2, no. 1: 3-22.

Viveiros de Castro, Eduardo. 2011. "Zeno and the Art of Anthropology: Of Lies, Beliefs, Paradoxes, and Other Truths.” Trans. Antonia Walford. Common Knowledge 17, no. 1: $128-145$.

Willerslev, Rane. 2004. "Spirits as Ready to Hand: A Phenomenological Study of Yukaghir Spiritual Knowledge and Dreaming.” Anthropological Theory 4, no. 4: 395-418.

Willerslev, Rane. 2007. Soul Hunters: Hunting, Animism, and Personhood among the Siberian Yukaghirs. Berkeley: University of California Press.

Willerslev, Rane. 2009. "The Optimal Sacrifice: A Study of Voluntary Death among the Siberian Chukchi." American Ethnologist 36, no. 4: 693-704.

Willerslev, Rane. 2011. "Frazer Strikes Back from the Armchair: A New Search for the Animist Soul." Journal of the Royal Anthropological Institute (n.s.) 17, no. 3: 504-526.

Willerslev, Rane. 2013a. "God on Trial: Human Sacrifice, Trickery and Faith." HAU: Journal of Ethnographic Theory 3, no. 1: 140-154.

Willerslev, Rane 2013b. "Rebirth and the Death Drive: Rethinking Freud's 'Mourning and Melancholia' through a Siberian Time Perspective.” Pp. 79-98 in Taming Time, Timing Death: Social Technologies and Ritual, ed. Dorthe R. Christensen and Rane Willerslev. London: Ashgate.

Willerslev, Rane. 2013c. "Taking Animism Seriously, but Perhaps Not Too Seriously?" Religion and Society: Advances in Research 4, no. 1: 41-57. 